\title{
Indian Archæological Investigation, Teaching, and Research*
}

\begin{abstract}
$\mathrm{T}$ HE mystery and fascination of Central Asia have been felt by three generations of travellers and scholars, and to-day we are blinded by treasures which a series of great excavations has given to the museums of Europe and Asia. It is in the museums and weighty reports of excavations that the historian must quarry for the raw material of history. The history of Central Asia has yet to be written; and for the most part we have to be content with brief and disconnected fragments, forming a background on which we must try to place the pieces of archæological evidence. The present expedition was undertaken in part with the object of directing attention to these problems, in part in the hope of providing a few fragments of evidence bearing on the great problem-that of chronology-in the study of the Buddhist art of Gandhara, the country which lay between the Indus and the Hindu Kush. The chronological scheme of Foucher, who wrote what still ranks as the standard work on Gandharan art, convenient and coherent as it is, is purely stylistic, and does not meet the requirements of the archæologist and historian, as had been demonstrated by the archæological investigations at Hadda of the French delegation, which has been at work in Afghanistan since 1922. Evidence of the influence of Gandharan art has come from various central Asian sources, extending so far as Turfan in Chinese Turkestan; but there is one blank in the record-Bactria and the Oxus territory.
\end{abstract}

The present expedition beyond the Indian frontier spent the summer months of 1938 excavating in the valley of Swat, and later, on the invitation of the director of the French delegation, and with the permission and assistance of the Afghan Government, in an archæological reconnaissance of the archæologically unexplored territory in the north of Afghanistan, covering a distance of two thousand miles.

In the Swat valley, Barikot was made the first camping site of the expedition in order to excavate some of the monastic and domestic sites in the three side valleys, which converge at this point. In the course of the two months which were spent here, a complete survey was made of all the Buddhist ruins, and a map was prepared showing not only the remains of stupas, monasteries and fortresses, but also of those of their dependent villages and terraced cultivations, with the view of determining the areas of settlement and the relations between domestic remains and areas of cultivation-in fact, to see what this small area looked like in Buddhist times. It was also hoped to determine the relation between specific pieces of sculpture and such domestic objects as might help, because of their appearance elsewhere in dateable contexts, to establish a chronology of Gandharan art.

Khanjar Khote, a typical monastic site, and one of a number excavated, consisted of a main courtyard, in which a stupa stands, surrounded by small stupas, following no fixed plan. They were evidently built by different donors and probably at different times.

* Abstract of a lecture on "The Results of the Recent Archæologica Expedition to Swat and Af henistan in Relation to the Presen Position of Indian Studies in this Country", by Evert Barger, lecture in medieval history in the University of Bristol, delivered before the Royal Society of Arts on November 30.
Behind is another courtyard, and cells for monks, some of which probably became niches in which a Buddha was set up, aligned along a road and at higher levels built in the hillside. The harvest from the small stupas was not rich-a number of pieces of blue schist showing scenes from Buddha's life in relief, two or three plaster heads, carved bases of model stupas and innumerable pieces of broken decoration. Amluk, a solitary site on a mountain top, was a more interesting place. Here the masonry was of unfamiliar pattern and the harvest richer. Hence came a $3 \mathrm{ft}$. seated Buddha of Foucher's 'late' variety. The circumstances in which the sculptures were found suggests destruction by Mohammedan invaders rather then the slow decay of which Huien Tsiang speaks.

Two members of the party excavated an acropolis $120 \mathrm{ft}$. high and covered with potsherds at Charbagh in Upper Swat, but with disappointing results. Some terra-cotta animal figures and one human torso may prove of value; but owing to the conservatism of the Indian potter, it is probable that we shall never achieve an intelligible chronology, or even classification of types of pottery, such as the European archæologist is accustomed to use as his guide.

Until the plaster heads have been compared with those from Takht-i-Bahi and Hadda, until seals, pottery, and iron objects have been studied, and corroded coins have been cleaned and deciphered, it cannot be said how much nearer this summer's work has brought us to an archæological, as distinet from a stylistic, chronology of Greco-Buddhist art, or whether any contribution has been made to the solution of another problem-why such a virile hybrid art sprang up in a comparatively small area on the Indian frontier and spread to Afghanistan and Chinese Turkestan. The main type of the Swat Buddha, however, has been established. He is squat and expressionless, with an Indian face. The Boddhisatva is not a saint, but an Indian prince in Greek dress.

At the end of July, two members of the party, the leader and one other, left for Kabul, and starting thence crossed the Hindu Kush into the Oxus plain, where a large number of the mounds with which Bactria is covered were examined and measured. At Kunduz, twenty-five miles south of the Oxus, there are a number of mounds and an impressive 'round' castle, with mud walls more than a hundred feet high and half a mile in circumference. It may be one of the centres by which the Sassanid kings kept their precarious hold on Bactria. On one site here a find was made which may be of importance-carved bases of Greek columns, which disprove the contention of M. Foucher, that the Hellenistic cities of Bactria were built of mud and sun-dried brick.

In the preparations for this expedition, although the keeper of the India Museum, London, and others were of the greatest assistance, the lack of a centre for Indian archæological studies in London, it was stated, had proved a grave handicap. Unless such expeditions as this are to be nothing more than a flash in the pan, if British work in India is to have a long-term programme, something more substantial is required than the occasional enterprise of one or 
two individuals. There must be a permanent centre in London for teaching and research, which would be a base for such expeditions, and for the study of the material they bring back. It is obvious that the personnel of expeditions should not be recruited in haphazard fashion from persons with few qualifications. There should be a team of specialists, engaged in teaching and research, who could be drawn upon for expedition work from time to time as occasion offered. It is sad to think that, at a time when India is much in our minds, at a time when our relations with her have reached a turning point in history, and she stands at the brink of a great experiment, there should be no professional home in London for the study and appreciation of Indian history and culture. Though there is still some doubt as to the function of a museum, those who know what the present keeper has done for the India Museum-a place where the student can now study each of its civilizations as a whole and in all its aspects-would agree that if there is to be a centre for teaching and research and a base for future expeditions, it can only be the India Museum.

A discussion followed the lecture (see p. 1029).

\section{The Future of Gaseous Fuel}

$\mathrm{T}$ 'HE town's gas industry is now well advanced into its second century of activity, although during the last half century it has, from time to time, been considered by observers as doomed to supersession sooner or later by other methods of using coal. Such opinions, based as they were on superficial knowledge, were always unwarranted, as revealed by the fact of steady growth of the use of gaseous fuel and the number of its applications. This growth has accompanied an increase in the efficiency of appliances. The present position and future of the industry have been the subject of several addresses in recent months.

Some time ago, Mr. E. V. Evans read a paper to the Royal Society of Arts on the importance of coal carbonization in the life of the nation, emphasizing the range and indispensability of its products. The modern tendency to avoid arduous and dirty tasks of domestic routine promotes the expansion of the use of gaseous fuel, which need not be stored and lends itself to automatic control. The same tendency is seen in many industrial heating operations, in spite of systems of charging which often do not encourage the free use of gas. It is only since 1920 that the sale of gas has been based on the heating value, and even now freedom to base sales on a rational system of charging is not complete. On this depends the expansion of use for large-scale operations.

Sir Harold Hartley, in his presidential address to the Society of British Gas Industries, said that the strength and vitality of an industry depends on the way it uses the resources of science. Research is the best insurance of its future, he said, and he referred to what the application of science has done to maintain and promote development of the use of gaseous fuel. The range and extent of this was given in very specific terms in a recent address of Sir David Milne Watson to the Fuel Luncheon Club, when he said that his own company-the Gas Light and Coke Co.-incurs annually an expenditure exceeding $£ 100,000$ on its research activities. In them all types of scientific skill are brought to bear on the problem of gas manufacture and purification, and utilization, including the handling of byproducts.

Mr. Evans, looking to the future, envisaged the possibility of producing gas without coke-something which a very large increase in the use of gaseous fuel might render urgently necessary. Already the industry has initiated research on the gasification of coal under pressure. The possibility of securing farreaching gasification and the production of large yields of methane and primary tars is already foreshadowed. If the early promise already shown is followed by economic success, the distribution of fuel in gaseous form will receive a great impetus. While these developments are proceeding, it will be interesting to watch the progress of the experiments made by the Soviet Union on the underground gasification of coal. Following on experiments, it is reported by the Russia Today Press Service that a commercial plant commenced operation in Gorlovka in 1937. Others are projected-one to supply Moscow-and claims are made for the cheapness of the gas.

H. J. H.

\section{University Events}

Cambridge.-C. B. Davies, of Trinity Hall, has been appointed for the present academical year to the studentship offered by Imperial Chemical Industries, Ltd.

The degree of Master of Arts has been conferred upon Dr. A. J. Bradley, assistant director of research in crystallography.

Sir Edward Mellanby, secretary of the Medical Research Council, has been appointed Rede lecturer for the year 1939 .

The following appointments in the Museum of Zoology have been made: F. T. Parrington, of Sidney Sussex College, to be director; H. B. Cott, of Selwyn College, to be curator of vertebrates, and Strickland curator; J. E. Smith, to be curator of invertebrates; Dr. G. C. Varley, of Sidney Sussex Collega, to be curator of insects. Dr. Varley has also been appointed University demonstrator in zoology.

The British Electrical and Allied Industries Research Association and the Permanent Magnet Association have offered to make jointly a grant of $£ 550$ a year to the University for the purpose of supporting research on magnetic materials under the direction of Prof. W. L. Bragg; and the Iron and Steel Industrial Research Council has offered to the University a grant at the rate of $£ 500$ a year for research on the structure of alloys, to be carried out in the Cavendish Laboratory under the same direction. In both cases, the grants will provide for the continuation of investigations which have been in progress for some time under Prof. Bragg's direction, first at the University of Manchester and afterwards at the National Physical Laboratory.

LONDON.-The title of professor emeritus of embryology in the University has been conferred on Prof. J. P. Hill, on his retirement from the University chair of embryology at University College, and that of professor emeritus of chemistry in the University on Prof. Samuel Smiles, on his retirement from the Daniell chair of chemistry at King's College. 